\title{
KONSEP PENDIDIKAN ISLAM MASA KINI
}

\author{
Fauti Subhan \\ (Dosen FITK IAIN Sunan Ampel Surabaya)
}

\begin{abstract}
Abstrak
Tulisan ini membahas tentang keterkaitan antara pendidikan Islam dengan berbagai elemen kehidupan. Keterkaitan antara sisi teoritis pendidikan Islam dengan sisi praktis pendidikan Islam juga disampaikan di sini. Secara kajian, dimensi teoritis dengan aplikatif pendidikan Islam dapat dibahas sendiri-sendiri, tetapi secara praktis, kedua dimensi tersebut tidak bisa lepas satu sama lain. Pada prinsipnya, persoalan pendidikan Islam tidak dapat dilepaskan dari beragam persoalan lainnya. Pendidikan Islam selalu terkait dengan berbagai elemen kehidupan, terutama manusia. Melalui pendidikan Islam manusia dapat tumbuh dan berkembang dengan baik. Sebaliknya, manusia (Muslim) juga menjadi aktor dari maju atau mundurnya pendidikan Islam. Antara umat Islam dan pendidikan Islam merupakan dua hal yang dapat diibaratkan seperti sekeping uang, yakni terdiri dari dua sisi yang berbeda tetapi tidak terpisah antara satu dengan lainnya.
\end{abstract}

Kata Kunci: Pendidikan Islam, Teoritis dan Praktis 


\section{A. Pendahuluan}

Dalam sejarah pertumbuhan dan perkembangan masyarakat, pendidikan senantiasa menjadi perhatian utama dalam rangka memajukan kehidupan generasi bangsa sejalan dengan tuntutan kemajuan zaman dan masyarakatnya. Menurut Nur Uhbiyati, sejarah pembentukan masyarakat dimulai dari keluarga adam dan hawa sebagai unit terkecil dari masyarakat besar umat manusia di muka bumi ini. Dalam keluarga adam itulah telah dimulai proses kependidikan umat manusia, meskipun dalam ruang lingkup terbatas sesuai dengan kebutuhan untuk mempertahankan hidupnya. ${ }^{1}$

Usaha mempertahankan hidup manusia terletak pada orientasi manusia ke arah 3 (tiga) hubungan, yaitu: (1) Hubungan manusia dengan Tuhan (Allah), (2) Hubungan manusia dengan sesama manusia, (3) Hubungan manusia dengan alam sekitar yang terdiri dari berbagai unsur kehidupan, seperti tumbuh-tumbuhan, binatang dan kekuatan alamiah yang ada.

Berpijak pada prinsip hubungan tersebut di atas, manusia mengembangkan proses pertumbuhan dan perkembangan kebudayaannya. Proses inilah yang mendorong manusia ke arah kemajuan hidup sejalan dengan tuntutan yang semakin meningkat. Manusia sebagai makhluk Allah telah dikaruniai kemampuankemampuan dasar yang bersifat ruhaniah dan jasmaniah agar mampu mempertahankan hidup serta memajukan kesejahteraannya.

Dalam kenyataannya, kemampuan dasar manusia merupakan modal dasar untuk mengembangkan kehidupannya di segala bidang. Sarana utama yang dibutuhkan untuk mengembangkan kehidupan manusia tidak lain adalah pendidikan, dalam dimensi yang setara dengan tingkat daya cipta, daya rasa dan daya karsa masyarakat beserta anggotaanggotanya.

Mengingat antara manusia dengan tuntutan hidupnya saling berpacu berkat dorongan dari ketiga daya (cipta, rasa dan karsa), maka pendidikan menjadi semakin penting. Dapat dikatakan, pendidikan merupakan kunci dari segala bentuk kemajuan hidup manusia sepanjang

\footnotetext{
${ }^{1}$ Nur Ubiyati, Ilmu Pendidikan Islam, Cet. II (Bandung: CV. Pustaka Setia, 1999), 9. 
sejarah. Melalui pendidikan umat manusia akan tumbuh dan berkembang dengan cepat seirama dengan kemajuan zaman dan tuntutan kehidupan masyarakat.

Pendidkan berkembang dari yang sederhana (primitif), yang berlangsung dalam zaman dimana manusia masih berada dalam ruang lingkup kehidupan yang serba sederhana. Tujuan-tujuannya pun amat terbatas pada hal-hal yang bersifat survival (bertahan hidup terhadap ancaman alam sekitar). Pada era ini pendidikan fokus pada keterampilan membuat alat-alat untuk mencari dan memproduksi bahan-bahan kebutuhan hidup. Setelah itu diciptakan pula alat-alat untuk mengolah hasil-hasil yang diperoleh menjadi bahan yang sesuai dengan kebutuhan. ${ }^{2}$

Ketika manusia dapat membentuk masyarakat yang semakin berbudaya dengan tuntutan hidup yang makin tinggi, pendidikan ditujukan bukan hanya pada pembinaan keterampilan, melainkan pada pengembangan kemampuan-kemampuan teoritis dan praktis berdasarkan konsep-konsep berpikir ilmiah. Kemampuan konsepsional demikian berpusat pada pengembangan kecerdasan manusia itu sendiri. Oleh karena itu, faktor daya pikir menjadi penggerak terhadap daya-daya lainnya untuk menciptakan peradaban dan kebudayaan yang semakin maju.

Dalam perkembangan sejarah pendidikan, manusia menciptakan bentuk-bentuk kehidupan yang bersifat dinamis. Oleh karena antara pendidikan dengan masyarakat (umat manusia) terjadi proses saling pengaruh mempengaruhi (interaktif). Di satu sisi masyarakat dengan citacitanya, mendorong terwujudnya pendidikan sebagai sarana untuk merealisasikan cita-cita tersebut, sedangkan di sisi lain pendidikan mencambuk masyarakatnya untuk bercita-cita lebih maju lagi. Bahkan pendidikan dalam suatu waktu tertentu menjadi pendobrak terhadap keterbelakangan cita-cita masyarakat. Dengan demikian antara pendidikan dan masyarakat terjadi perpacuan (kompetisi) untuk maju. Itulah salah satu ciri dari masyarakat yang dinamis dimana pendidikan menjadi tumpuan kemajuan perkembangan hidupnya.

Dalam masyarakat Islam, pendidikan juga merupakan kunci kemajuan. Masyarakat Islam yang berkembang sejak zaman Nabi

\footnotetext{
${ }^{2}$ Nur Ubiyati, Ilmu Pendidikan Islam, 10.
} 
Muhammad Saw melaksanakan misi suci menyebarkan agamanya, antara lain melalui pendidikan. Sumber-sumber ajaran Islam yang berupa AlQur'an, Al-Hadits, dan Ijtihad ${ }^{3}$ banyak mendorong pemeluknya untuk menciptakan pola kemajuan hidup yang dapat menyejahterakan pribadi dan masyarakat, sehingga dengan kesejahteraan yang berhasil diciptakannya, manusia secara individual dan sosial, mampu meningkatkan derajat dan martabatnya, baik bagi kehidupannya di dunia maupun di akhirat nanti. Derajat dan martabat sebagai khalifah di muka bumi dapat diraih berkat usaha pendidikan yang bercorak Islami.

Proses kependidikan Islam berusaha merealisasikan misi Islam dalam tiap pribadi manusia, yaitu menjadikan manusia sejahtera dan bahagia dalam cita-cita Islam. Cita-cita Islam mencerminkan nilai-nilai normatif dari Allah yang bersifat abadi dan absolut, dan tidak mengikuti selera nafsu dan budaya manusia yang berubah-ubah menurut tempat dan waktu.

Nilai-nilai Islam yang demikian itulah yang ditumbuhkembangkan dalam diri pribadi manusia melalui proses transformasi kependidikan. Proses kependidikan yang mentransformasikan nilai tersebut selalu berorientasi kepada kekuasaan Allah dan iradah-Nya yang menentukan keberhasilannya. Hasil dari proses kependidikan Islam akan tetap berada dalam lingkaran hubungan vertikal dengan Allah, dan hubungan horizontal dengan masyarakat dan alam sekitarnya.

\section{B. Makna Pendidikan Islam}

Ketika pendidikan diartikan sebagai latihan mental, moral dan fisik (jasmaniah) yang menghasilkan manusia berbudaya tinggi untuk melaksanakan tugas kewajiban dan tanggung jawab dalam masyarakat selaku hamba Allah, maka kependidikan berarti menumbuh-kembangkan personalitas (kepribadian) serta menanamkan rasa tanggung jawab. Kependidikan bagi manusia menyerupai makanan yang berfungsi memberikan vitamin bagi pertumbuhan dan perkembangan manusia. ${ }^{4}$

\footnotetext{
3 Abd. Chayyi Fanany, Ilmu Pendidikan Islam (Surabaya: Taruna Media Pustaka, 2010), 19-29.

${ }^{4}$ Nur Ubiyati, Ilmu Pendidikan Islam, 12. 
Sasaran pendidikan berbeda-beda menurut pandangan hidup masing-masing pendidik atau lembaga pendidikan. Oleh karenanya maka perlu dirumuskan pandangan hidup Islam yang mengarahkan sasaran pendidikan Islam. Umat Islam telah diajarkan dalam Al-Qur'an Surat AlImran Ayat 19 yang artinya: "Sesungguhnya Islam itu adalah agama yang benar di sisi Allah" (QS: Al-Imran: 19). ${ }^{5}$

Apabila manusia berpredikat Muslim, benar-benar menjadi penganut agama yang baik, ia harus menaati ajaran Islam dan menjaga agar rahmat Allah tetap berada pada dirinya. Ia harus mampu memahami, menghayati dan mengamalkan ajarannya yang didorong oleh iman sesuai dengan aqidah Islamiah. Demikianlah, sehingga manusia harus dididik melalui proses pendidikan Islam.

Berdasarkan pandangan di atas, maka pendidikan Islam merupakan sistem pendidikan yang dapat memberikan kemampuan kepada seseorang untuk memimpin kehidupannya sesuai dengan cita-cita Islam, karena nilai-nilai Islam telah menjiwai dan mewarnai corak kepribadiannya. Dengan kata lain, manusia Muslim yang telah mendapatkan pendidikan Islam itu harus mampu hidup di dalam kedamaian dan kesejahteraan sebagaimana yang diharapkan oleh cita-cita Islam. ${ }^{6}$

Sementara itu, ilmu pendidikan Islam merupakan pengetahuan tentang pendidikan agama Islam. Arti lain menyebutkan, ilmu pendidikan Islam adalah ilmu yang mengajarkan bagaimana menjadi guru agama yang baik. Ilmu pendidikan Islam berisi tentang materi-materi yang akan menjadi bekal bagi guru bidang studi pendidikan agama Islam.

Ilmu pendidikan Islam bukan hanya ilmu tentang pendidikan Islam, melainkan ilmu pendidikan yang Islami, yaitu uraian sistematis tentang ajaran Islam mengenai berbagai aspek dan komponen pendidikan. Dengan demikian, pengetahuan tentang ajaran Islam mengenai pendidikan juga dapat dikatakan sebagai bagian daripada ilmu pendidikan

\footnotetext{
5 Al-Quran dan Terjemahnya (Jakarta: Yayasan Penyelenggara Penterjemah/Pentafsir Al-Quran, 1971), 78.

${ }^{6}$ Nur Ubiyati, Ilmu Pendidikan Islam, 13.
} 
Islam. Jadi ilmu pendidikan Islam adalah ilmu pendidikan yang Islami, atau ilmu pendidikan dalam perspektif Islam. ${ }^{7}$

Dengan demikian pendidikan Islam merupakan suatu sistem pendidikan yang mencakup seluruh aspek kehidupan yang dibutuhkan oleh hamba Allah, yang bersumber dari Al-Quran dan Al-Hadits serta Ijtihad para Ulama Muslim, untuk kepentingan duniawi dan ukhrawi. Oleh karenanya, semua cabang ilmu pengetahuan yang mengandung nilai manfaat dan maslahat merupakan ruang lingkup pendidikan Islam.

Oleh karena begitu luasnya jangkauan yang harus digarap oleh pendidikan Islam, maka pendidikan Islam tidak menganut sistem tertutup melainkan sistem terbuka terhadap tuntutan kesejahteraan umat manusia, baik tuntutan di bidang ilmu pengetahuan dan teknologi maupun tuntutan pemenuhan kebutuhan hidup ruhaniah. Kebutuhan itu semakin meluas sejalan dengan meluasnya tuntutan hidup manusia itu sendiri.

Apabila ditinjau dari aspek pengalaman, pendidikan Islam berwatak akomodatif terhadap tuntutan kemajuan zaman yang ruang lingkupnya berada di dalam kerangka acuan norma-norma kehidupan Islam. Ilmu pendidikan Islam merupakan studi tentang sistem dan proses kependidikan yang berdasarkan ajaran Islam untuk mencapai produk atau tujuan baik bersifat teoritis maupun teknis.

\section{Pendidikan Islam Teoritis dan Praktis}

Pendidikan memegang peranan yang menentukan eksistensi dan perkembangan masyarakat, karena pendidikan merupakan usaha melestarikan, mengalihkan dan mentransformasikan nilai-nilai kebudayaan dalam segala aspek dan jenisnya kepada generasi berikutnya. Begitu juga dengan peranan pendidikan Islam di kalangan umat Islam merupakan salah satu bentuk manifestasi dari cita-cita hidup Islam untuk melestarikan, mengalihkan dan menanamkan (internalisasi) dan mentransformasikan nilai-nilai Islam tersebut kepada pribadi generasi berikutnya sehingga nilai-nilai kultural religius yang dicita-citakan dapat tetap berfungsi dan berkembang dalam masyarakat dari waktu ke waktu.

Apabila dilihat dari segi kehidupan kultural umat manusia, pendidikan Islam merupakan salah satu alat kebudayaan bagi masyarakat.

\footnotetext{
${ }^{7}$ Abd. Chayyi Fanany, Ilmu Pendidikan Islam, 1. 
Sebagai suatu alat, pendidikan Islam dapat difungsikan untuk mengarahkan pertumbuhan dan perkembangan hidup manusia, sebagai makhluk pribadi dan makhluk sosial untuk memperoleh kesejahteraan hidup di dunia dan kebahagiaan hidup di akhirat. Lebih dari itu, kebudayaan merupakan penopang daripada pembangunan. Meskipun pembangunan dapat saja mengabaikan kebudayaan, namun bagaimanapun kebudayaan akan mempengaruhi jalannya pembangunan. ${ }^{8}$

Dalam hal ini, kedayagunaan pendidikan sebagai alat pembudayaan sangat bergantung kepada pemegang alat tersebut, yaitu para pendidik. Para pendidik memegang posisi kunci yang banyak menentukan keberhasilan proses pendidikan, sehingga mereka dituntut persyaratan tertentu, baik teoritis maupun praktis, dalam pelaksanaan tugasnya. Sementara itu faktor-faktor yang bersifat internal seperti bakat atau pembawaan anak didik dan faktor eksternal seperti lingkungan dalam segala dimensinya menjadi penopang dari proses ikhtiar para pendidik.

Untuk memperoleh gambaran tentang pola berpikir dan berbuat dalam pelaksanaan pendidikan Islam diperlukan kerangka pikir teoritis yang mengandung konsep-konsep ilmiah tentang kependidikan Islam, di samping konsep-konsep operasionalnya dalam masyarakat. Dengan kata lain bahwa untuk memperoleh suatu keberhasilan dalam proses pendidikan Islam, diperlukan adanya ilmu pengetahuan tentang pendidikan Islam baik yang bersifat teoritis maupun aplikatif. Argumentasi perlunya ilmu pendidikan Islam teoritis dapat dilihat dari beberapa alasan sebagai berikut:

1. Pendidikan sebagai usaha membentuk pribadi manusia harus melalui proses yang panjang, dengan hasil (resultant) yang tidak dapat diketahui dengan segera, berbeda dengan membentuk benda mati yang dapat dilakukan sesuai dengan keinginan pembuatnya. Dalam proses pembentukan tersebut diperlukan suatu perhitungan yang matang dan hati-hati berdasarkan pandangan dan pikiran-pikiran atau teori-teori yang tepat, sehingga kegagalan dan kesalahan-kesalahan langkah pembentukan terhadap anak didik dapat dihindarkan. Oleh

${ }^{8}$ Abdurrahman Wahid, Menggerakkan Tradisi, Cet. II (Yogyakarta: LKiS, 2007), xiii. 
karena lapangan tugas dan sasaran pendidikan adalah makhluk yang sedang hidup tumbuh dan berkembang yang mengandung berbagai kemungkinan, apabila salah bentuk, maka akan sulit memperbaikinya.

2. Pendidikan Islam, yang bersumberkan nilai-nilai ajaran agama Islam di samping menanamkan atau membentuk sikap hidup yang dijiwai nilai-nilai tersebut, juga mengembangkan kemampuan berilmu pengetahuan sejalan dengan nilai-nilai Islam yang melandasinya, merupakan proses ikhtiari yang secara pedagogis mampu mengembangkan hidup anak didik ke arah kedewasaan atau kematangan yang menguntungkan dirinya. Oleh karena itu, usaha ikhtiari tersebut tidak dapat dilakukan hanya berdasarkan atas trias and error (coba-coba) atau atas keinginan dan kemauan pendidik tanpa dilandasi dengan teori-teori kependidikan yang dapat dipertanggung jawabkan secara ilmiah pedagogis.

3. Islam merupakan agama wahyu yang diturunkan oleh Allah dengan tujuan untuk menyejahterakan dan membahagiakan hidup dan kehidupan umat manusia di dunia dan akhirat, mempunyai arti fungsional dan aktual dalam diri manusia bilamana dikembangkan melalui proses kependidikan yang sistematis. Oleh karena itu teoriteori pendidikan Islam yang disusun secara sistematis merupakan kompas bagi proses tersebut.

4. Ruang lingkup kependidikan Islam adalah mencakup segala bidang kehidupan manusia di dunia dimana manusia mampu memanfaatkan sebagai tempat menanam benih-benih amaliah yang buahnya akan dipetik di akhirat nanti, maka pembentukan sikap dan nilai-nilai amaliah Islamiah dalam pribadi manusia baru dapat efektif bilamana dilakukan melalui proses kependidikan yang berjalan di atas kaidahkaidah ilmu pengetahuan kependidikan.

5. Teori-teori, hipotesis dan sumsi-asumsi kependidikan yang bersumberkan ajaran Islam sampai kini masih belum tersusun secara ilmiah meskipun bahan-bahan bakunya telah tersedia, baik dalam kitab suci al-Quran dan al-Hadits maupun pandangan ulama. Untuk 
itu diperlukan penyusunan secara sistematis ilmiah yang didukung dengan hasil penelitian yang luas. ${ }^{9}$

Dari segi teoritis, pendidikan Islam merupakan konsep berpikir yang bersifat mendalam dan terperinci tentang masalah kependidikan yang bersumberkan ajaran Islam dari rumusan-rumusan tentang konsep dasar, pola, sistem, tujuan, metode dan materi (substansi) kependidikan Islam yang disusun menjadi suatu ilmu yang bulat.

Pada tinjauan ini diungkapkan bagaimana pandangan Islam tentang masalah kependidikan yang mungkin dapat diaplikasikan melalui proses yang sesuai dengan kaidah-kaidah ilmu pengetahuan kependidikan pada umumnya. Dengan kata lain ilmu kependidikan Islam dalam teoriteorinya mengnadung konformitas (kesesuaian) pandangan dengan teoriteori dalam ilmu pedagogik terutama yang menyangkut anak didik, pendidik, alat-alat, dan cita-cita. Dalam teori kependidikan Islam terkandung niai-nilai ilmiah pedagogik yang absah dalam dunia ilmu pengetahuan, khususnya dunia ilmu pendidkan.

Beragam konsepsi yang berasal dari pandangan agama Islam dari al-Quran dan al-Hadits telah diungkapkan oleh para sahabat atau ulama sebagai sumber bahan penganalisaan bagi pembentukan teori-teori kependidikan Islam itu. Dalam upaya mengembangkan pendidikan Islam itulah diperlukan kemampuan analisis para mujtahid pendidikan Islam.

Dalam memasuki domain pemikiran yang aplikatif, pendidikan Islam lebih banyak menitikberatkan pada masalah bagaimana proses kependidikan harus dilaksanakan dalam sistem, pola dan program dengan berbagai metode yang tepat untuk mencapai tujuan-tujuan. Hal pertama yang perlu diperhatikan adalah masalah operasional bagaimana agar proses kependidikan yang dilaksanakan itu dapat berjalan, efektif dan efisien dalam arti mmapu membawakan misi agama Islam. Fakta dan informasinya dapat diperoleh dalam sejarah perkembangan pendidikan Islam dari zaman ke zaman.

Ketika suatu komunitas memandang bahwa manausia tidak memerlukan lagi norma dan nilai-nilai agama untuk memperkokoh kemajuan hidupnya, maka usaha pendidikan yang dilakukan akan mengalami kegersangan nilai-nilai kultural dari agama yang

\footnotetext{
${ }^{9}$ Nur Uhbiyati, Ilmu Pendidikan Islam, 15-16.
} 
diperlukannya. Gejala demikian merupakan lampu merah bagi kemunduran lembaga-lembaga kependidikan dari percaturan dunia kependidikan.

Pendidikan Islam baik teoritis maupun praktis mengalami kecenderungan untuk berkembang dari waktu ke waktu sesuai dengan tempat dan momen-momen yang dilaluinya. Tingkat perkembangan kebudayaan atau peradaban masyarakat itulah yang banyak mewarnai corak dan isi pendidikan Islam dalam arti bahwa tingkat kemajuan berpikir masyarakat Islam untuk memperoleh kemajuan hidupnya dimana nilai-nilai kebudayaan yang dimiliki menjadi latar belakangnya, merupakan faktor yang mempengaruhi perkembangan pendidikan Islam pada saat atau tingkat tertentu. Dari situ umat Islam akan mendapat pola dan bentuk operasional kependidikan Islam yang berbeda-beda dari satu masyarakat ke masyarakat lainnya, meskipun dasar dan tujuannya sama. Pendidikan Islam banyak berbaur dengan kebudayaan, karena itu kebudayaan harus diikat dengan norma, etika dan agama. Agama Islam tidak saja sebagai pengikat, melainkan juga sebagai sumber suatu kebudayaan. Kebudayaan Islam diciptakan oleh orang Islam, karena orang Islam berpikir dan bertindak sesuai dengan pedoman yang digariskan oleh ajaran Islam. ${ }^{10}$

Pandangan dasar yang berhubungan dengan pengembangan teoritis ilmu pendidikan Islam mencakup permasalahan kependidikan yang pada garis besarnya dapat dianalisis dari aspek-aspek konsepsional, antara lain sebagai berikut:

1. Hakikat pendidkan Islam adalah proses membimbing dan mengarahkan pertumbuhan dan perkembangan anak didik agar menjadi manusia dewasa sesuai tujuan pendidikan Islam.

2. Asas pendidikan Islam adalah asas perkembangan dan pertumbuhan dalam prikehidupan yang berkeseimbangan antara kehidupan duniawiyah dan ukhrawiyah, jasmaniyah dan ruhaniyah atau antara kehidupan meteriil dan mental spiritual.

3. Modal dasar pendidikan Islam adalah kemampuan dasar (fitrah) untuk berkembang dari masing-masing pribadi manusia sebagai

${ }^{10}$ Zakiah Daradjat, dkk, Ilmu Pendidikan Islam, Cet. ke 8 (Jakarta: Bumi AksaraDepag RI, 2008), 7.

Jurnal Pendidikan Agama Islam

Volume 02 Nomor 02 November 2013

Hal 362 - 373 
karunia Allah. Kemampuan dasar ini merupakan potensi mentalspiritual dan fisik yang diciptakan Allah sebagai fitrah yang tidak bisa diubah atau dihapus oleh siapapun, akan tetapi dapat diarahkan perkembangannya dalam proses pendidikan sampai titik optimal yang berakhir pada takdir Allah. Bagi masing-masing manusia kelainan watak kepribadian akibat berbeda-bedanya kemampuan dasar dan keturunan merupakan sebuah realitas individual yang menuntut kesempatan berkembang melalui proses kependidikan yang cukup memadai (favourable).

4. Sasaran strategis pendidikan Islam adalah menanamkan dan mengembangkan nilai-nilai agama dan nilai-nilai ilmu pengetahuan secara mendalam dan meluas dalam pribadi anak didik, sehingga akan terbentuk dalam dirinya sikap beriman dan bertakwa dengan kemampuan mengembangkan ilmu pengetahuan dalam kehidupan sehari-hari. Dengan istilah lain sasaran pendidikan Islam adalah mengintegrasikan iman dan takwa dengan ilmu pengetahuan dalam pribadi manusia untuk mewujudkan kesejahteraan hidup di dunia dan kebahagiaan di akhirat.

5. Ruang lingkup pendidikan Islam mencakup kegiatan-kegiatan kependidikan yang dilakukan secara konsisten dan berkesinambungan dalam bidang atau lapangan hidup manusia yang meliputi: ${ }^{11}$

a. Lapangan hidup keagamaan, agar perkembangan pribadi manusia sesuai dengan norma-norma ajaran Islam.

b. Lapangan hidup keluarga, agar berkembang menjadi keluarga yang sejahtera.

c. Lapangan hidup ekonomi, agar dapat berkembang dalam sistem ekonomi yang bebas dari penghisapan manusia oleh manusia.

d. Lapangan hidup kemasyarakatan, agar terbina masyarakat yang adil dan makmur di bawah ridha dan ampunan Allah SWT.

e. Lapangan hidup politik, agar tercipta sistem demokrasi yang sehat dan dinamis sesuai ajaran Islam.

${ }^{11}$ Anwar Rasyid, Ilmu Pendidikan Islam (Teori \& Aplikatif) (Surabaya: TMP, 2011). 
f. Lapangan hidup seni budaya, agar menjadikan hidup manusia penuh keindahan dan kegairahan yang tidak gersang dari nilai moral agama.

g. Lapangan hidup ilmu pengetahuan, agar berkembang menjadi alat untuk mencapai kesejahteraan hidup umat manusia yang dikendalikan oleh iman.

6. Metode yang digunakan dalam proses pencapaian tujuan adalah metode yang didasarkan atas pendekatan-pendekatan keagamaan (religius), kemanusiaan (humanity) dan ilmu pengetahuan (scientific); Sistem pendekatan tersebut dilakukan atas landasan nilainilai moral keagamaan. Dengan demikian semboyan kaum atheis yang menyatakan tujuan dapat menghalalkan segala cara (the aim saintifies the means), bertentangan dengan pendidikan Islam. ${ }^{12}$

\section{Persyaratan Disiplin Ilmu Pendidikan Islam}

Menurut ketentuan ilmu pengetahuan sosial (social science) secara umum, pesyaratan yang harus dipenuhi oleh pendidikan Islam sebagai disiplin ilmu adalah mencakup hal-hal sebagai berikut:

1. Memiliki objek pembahasan yang jelas dan bercorak khas kependidikan yang ditunjang dengan ilmu pengetahuan lain yang relevan.

2. Mempunyai pandangan, teori, asumsi atau hipotesa-hipotesa yang bercorak kependidikan (pedagogis) yang bersumberkan ajaran Islam.

3. Memilliki metode penganalisaan yang sesuai dengan tuntutan dari corak keilmuan kependidikan yang bernafaskan Islam atas dasar pendekatan-pendekatan yang relevan dengan corak dan watak keilmuan tersebut.

4. Memiliki struktur keilmuan yang definitif yang mengandung suatu kebulatan dari bagian-bagian yang satu sama lain berkaitan sebagai suatu sistem keilmuan yang mandiri (tidak bergantung pada sistem keilmuan yang lain). ${ }^{13}$

\footnotetext{
${ }^{12}$ Nur Uhbiyati, Ilmu Pendidikan Islam, 18-20.

${ }^{13}$ Nur Uhbiyati, Ilmu Pendidikan Islam, 20-21.

Jurnal Pendidikan Agama Islam

Volume 02 Nomor 02 November 2013

Hal 364 - 373
} 
Dalam hal sistematisasi bahan-bahan pengetahuan tentang kependidikan Islam sehingga menjadi suatu ilmu yang terpadu (integral), diperlukan sikap dan pandangan objektif dalam pola pikir yang menyeluruh tentang sasaran tugas kependidikan yang harus dilaksanakan. Sasaran utama tugas kependidikan tersebut adalah anak didik yang masih berada dalam taraf perkembangan dan pertumbuhan melalui proses secara bertahap menuju ke arah kedewasaannya.

Setiap tahap perkembangan dan pertumbuhan tersebut senantiasa membawa ciri-ciri kemampuan kejiwaan dan kejasmanian yang menuntut pelayanan atau pengetrapan metode pendidikan yang sesuai dari para pendidik. Melalui teori-teori psikologi, ilmu pendidikan Islam akan mampu melihat secara objektif tentang kebutuhan perkembangan dan pertumbuhan anak didik yang perlu disediakan oleh pendidik. Oleh karena sasaran pendidikan tersebut mencakup masalah psikologis dan fisiologis, maka pendidikan Islam tidak bisa melepaskan diri dari kajian psikologi, terutama psikologi pendidikan. Antara kedua ilmu ini saling terkait secara sinergis.

Dalam hubungannya dengan proses menanamkan nilai-nilai agama dan membimbing ke arah kehidupan beragama, ilmu pendidikan Islam memerlukan juga bantuan psikologi agama, karena psikologi agama menunjukkan tentang tingkat-tingkat kemampuan anak dalam menerima nilai-nilai agama beserta kepekaannya (sensitivitasnya) terhadap penerimaan nilai-nilai tersebut.

Dalam kaitan dengan pelaksanaan operasional kependidikan Islam, maka sebagai suatu kebulatan ilmu yang ilmiah, pendidikan Islam perlu memiliki pandangan yang feasible (dapat dilaksanakan secara aplikatif) dan memiliki kelenturan dalam teori-teori atau konsepsikonsepsi kependidikan. Ia juga merupakan eksperimentasi teori pendidikan Islam yang bertugas memfungsikan ide-ide kependidikan dalam proses pelaksanaan baik dalam bentuk formal, seperti di sekolah maupun non-formal seperti Majlis Taklim, Pondok Pesantren, dan informal, seperti pendidikan keluarga.

Dengan demikian, fungsi ilmu pendidikan Islam secara aplikatif mencakup tiga (3) macam tugas sebagai berikut: 
1. Ia melakukan pembuktian terhadap teori-teori kependidikan Islam yang merangkum aspirasi atau cita-cita Islam yang harus diikhtiarkan agar menjadi kenyataan.

2. Ia memberikan bahan-bahan informasi tentang pelaksanaan pendidikan dalam segala aspeknya bagi pengembangan ilmu pengetahuan pendidikan Islam tersebut. Ia memberikan bahan masukan yang berharga (input) kepada ilmu ini.

3. Mekanisme proses kependidikan Islam dari segi operasional dapat dipersamakan dengan proses mekanisme yang berasal dari penerimaan input (bahan masukan), lalu diproses dalam kegiatan pendidikan (dalam bentuk kelembagaan atau non-kelembagaan yang disebut throughput), kemudian berakhir pada output (hasil yang diharapkan). Dari hasil yang diharapkan itu timbul umpan balik (feed back) yang mengoreksi bahan masukan (input). Mekanisme proses macam ini berlangsung terus selama proses kependidikan terjadi. Semakin banyak diperoleh bahan masukan (input) dari pengalaman operasional itu, semakin berkembang pula ilmu pendidikan Islam.

4. Di samping itu, menjadi pengoreksi (korektor) terhadap kekurangan teori-teori yang dipegangi oleh ilmu pendidikan Islam, sehingga kemungkinan pertemuan antara keduanya makin bersifat interaktif (saling mempengaruhi). ${ }^{14}$

Sebagaimana ilmu kependidikan teoritis, dalam pelaksanaan kependidikan Islam aplikatif diperlukan pendekatan-pendekatan yang memungkinkan perluasan pandangan para pendidik terhadap objek pendidikan yang dihadapi, sepanjang pendekatan tersebut mempunyai keterkaitan (relevansi) dengan tugas kependidikan. Pendekatan filosofis, psikologis, sosiologis, kultural, apalagi pedagogis dan agamis sangat diperlukan bagi perluasan dan pendalaman pandangan kependidikan dalam bidang operasional.

Oleh karena sasaran pendidikan Islam adalah manusia baik yang belum dewasa maupun yang sudah dewasa, maka teori dan praktik dalam kependidikan Islam harus mampu memberikan pandangan atau pemikiran yang tepat dan terarah tentang kemungkinan-kemungkinan yang objektif dari proses pertumbuhan dan perkembangan sasaran kependidikan

\footnotetext{
${ }^{14}$ Nur Uhbiyati, Ilmu Pendidikan Islam, 22. 
tersebut. Hal demikian menuntut kepada ilmu pendidikan Islam baik teoritis maupun praktis untuk menetapkan kaidah atau pedoman konsepsional dan operasional yang dapat menunjukkan alternatifalternatif dalam proses mengerahkan pertumbuhan dan perkembangannya menuju ke arah pendewasaan individualitas (pendirian pribadi), sosialitas (kemampuan kemasyarakatan) dan moralitas (kemampuan berakhlak susila).

Allah telah menciptakan semua makhluk-Nya berdasarkan fitrahNya. Akan tetapi fitrah Allah untuk manusia yang di sini diterjemahkan dengan potensi dapat dididik dan mendidik, memiliki kemungkinan berkembang dan meningkat sehingga kemampuannya dapat melampaui jauh dari kemampuan fisiknya yang tidak berkembang. ${ }^{15}$

Ilmu pendidikan Islam yang berorientasi pada tugas, harus mendasari dirinya dengan pelbagai tinjauan dari sudut ilmu yang diperlukan, juga tidak dapat melepaskan diri dari pandangan filsafat pendidikan Islam, mengingat filsafat pendidikan bertugas memberikan penganalisaan tentang problema-problema kependidikan yang dihadapi oleh ilmu pendidikan Islam, juga mendasari dan mengarahkan tujuan ilmu pendidikan Islam. Melalui pandangan filosofis, maka ilmu pendidikan Islam mendapatkan kompas dalam usaha pengembangannya lebih lanjut sehingga sebagai ilmu pengetahuan, ia akan mampu memberikan pemikiran konsepsional tentang pemecahan problema yang lebih terperinci dan lebih mendalam, terarah dan proporsional.

\section{E. Analisis Terhadap Pendidikan Islam Masa Kini}

Dalam rangka pengembangan ilmu, diperlukan analisis dan pengkajian bahan-bahan yang diperoleh dari kegiatan empiris, yaitu kegiatan penelitian baik yang berupa data kualitatif maupun kuantitatif (angka-angka) atau informasi dan sebagainya. Oleh karena itu, antara teori dalam ilmu pendidikan Islam dengan fakta yang berkembang dalam lapangan empiris harus saling berkaitan. Lebih lanjut dapat digambarkan sebagai berikut:

1. Teori menetapkan adanya hubungan dari fakta yang ada;

15 M. Jindar Wahyudi, Nalar Pendidikan Qurani (Yogyakarta: Apeiron Philotes, 2006), 84-85. 
2. Teori mengembangkan sistem klasifikasi dan struktur dari konsepkonsep;

3. Teori harus dapat mengikhtisarkan fakta-fakta, sebuah teori harus mampu menerangkan sejumlah besar fakta;

4. Teori harus dapat meramalkan fakta; salah satu tugas dari sebuah teori adalah dapat meramalkan kejadian;

5. Teori harus dapat menunjukkan kebutuhan-kebutuhan untuk dikembangkan dalam penelitian lebih lanjut dalam rangka pengembangan teori tersebut. ${ }^{16}$

Teori merupakan suatu sistem yang bulat dari prinsip-prinsip definisi-definisi, hipotesa-hipotesa dan observasi yang tersusun sedemikian rupa sehingga secara sederhana dapat menjelaskan saling hubungannya antara berbagai variabel. ${ }^{17}$ Jadi suatu teori pada hakikatnya adalah suatu konsepsi berpikir manusia tentang suatu bidang kehidupan yang tersusun berdasarkan fakta-fakta yang saling berkaitan dengan yang mendukungnya sehingga menjadi suatu bentuk pemikiran yang dapat teruji kebenarannya dalam praktik.

Oleh karena itu antara teori dan praktik kependidikan di satu pihak harus saling berhubungan, dan di lain pihak teori dan praktik kependidikan harus dikembangkan melalui kegiatan penelitian sebagai sarana untuk memperkaya dan sekaligus mengoreksi konsep-konsep operasional pendidikan tersebut. Sehubungan dengan ilmu pendidikan Islam yang bersifat teoritis dan aplikatif, agar keduanya bercorak ilmiah, diperlukan usaha sistematisasi yang well organized (tersusun baik) yang mampu memberikan deskripsi tentang fakta atau data dari pengalaman dalam pengertian yang sesederhana mungkin.

Supaya corak teoritis dari keilmuan kependidikan Islam tidak kurang, maka teori-teori yang dirumuskan perlu diambilkan dari hipotesahipotesa yang dianalisis melalui proses pemikiran yang bersifat deduktif dan induktif serta analisis-analisis. Suatu fakta atau beberapa pengalaman yang relevan merupakan bahan-bahan analisis yang dijadikan pembuktian atau kebenaran hipotesis tersebut.

\footnotetext{
${ }^{16}$ Nur Uhbiyati, Ilmu Pendidikan Islam, 24-26.

${ }^{17}$ Gilbert Sax, Empirical Foundations of Education Research, 12; Lihat dalam Nur Uhbiyati, Ilmu Pendidikan Islam, 28

Jurnal Pendidikan Agama Islam

Volume 02 Nomor 02 November 2013

Hal 368 - 373
} 
Ilmu pendidikan Islam teoritis juga mengandung watak dan ciri praktis, dengan kata lain dapat dilaksanakan dalam praktik, antara keduanya saling mengembangkan. Mengingat watak dan ciri ini, maka tidak perlu ada pemisahan antara ilmu yang bersifat teoritis dan praktis; keduanya telah tercakup dalam pengertian ilmu itu sendiri. Akan tetapi dengan adanya pemisahan tersebut akan memudahkan penganalisaan lebih lanjut tentang tugas, dan fungsi masing-masing. Teori tanpa praktik akan kurang bermakna dan praktik tanpa teori akan absurd (kabur). Oleh karena itu suatu teori yang baik adalah bila mengandung formulasiformulasi yang tentatif (yang dapat dirubah) untuk disesuaikan dengan fakta-fakta.

Teori lupa, misalnya, merupakan hasil dari proses penelitian tentang belajar seseorang. Teori lupa menyatakan bahwa mengingat-ingat merupakan suatu fungsi psikologis yang menghilangkan sejumlah interference. Seandainya teori ini diterima secara tentatif, maka lalu apa yang dapat diramalkan tentang lupa itu? Untuk itu seseorang harus mencapai fakta-fakta yang ditetapkan menjadi sasaran penelitian. Misalnya, mengingat-ingat bahan pelajaran lain yang dipelajari sesudah mempelajari bahan-bahan tertentu, atau oleh karena kurang tidur, maka ingatan seseorang menurun, sehingga sebagian besar bahan pelajaran terlupakan. ${ }^{18}$

Setiap teori harus mampu melahirkan hipotesa-hipotesa yang diklasifikasikan melalui tes eksperimental, juga harus dapat memperluas aspek-aspek teori itu sendiri serta tidak membatasi dengan berbagai kendala. Oleh karena itu sebuah teori baru dapat mengembangkan suatu ilmu bila dibantu oleh fakta-fakta yang relevan melalui cara sebagai berikut:

1. Fakta mendorong pembentukan suatu teori. Semakin banyak fakta yang diperoleh dalam lingkup ilmu pengetahuan, maka semakin besar kegunaannya untuk menyusun dan menjelaskan fakta-fakta yang dapat memperkuat kaitan antara ilmu pengetahuan teoritis dengan fakta-fakta. Dalam kaitan inilah diperlukan pemilihan objek

${ }^{18}$ M. Arifin, Psikologi dan Beberapa Aspek Kehidupan Ruhaniah Manusia (Jakarta: Bulan Bintang, 1977), 208-210. 
penelitian yang pada gilirannya akan mengembangkan suatu teori dari ilmu pengetahuan tersebut.

2. Fakta dapat mengubah suatu teori yang telah terbentuk karena adanya fakta-fakta baru yang ditemukan. Teori tersebut kemudian dibentuk kembali sehingga ruang lingkup dan keluasannya serta kedalamannya lebih akurat (tepat). ${ }^{19}$

Para ahli teori pendidikan telah memberikan dasar pandangan tentang pekerjaan pendidik yang harus berlangsung secara hati-hati. Di situ diperlukan pedoman teoritis untuk diamalkan sesuai tujuannya dan merupakan ujung dari kelangsungan proses yang berkesinambungan dengan pelaksanaan praktis pada ujung lainnya (...theory might be considered to be at one of continuum with practical matters at the other end). Oleh karena itu suatu teori pada hakikatnya merupakan suatu bentuk kontemplasi, sedangkan masalah praktis melibatkan suatu pekerjaan yang aktual. Jadi ilmu pengetahuan itu menyangkut berpikir dan merenungkan, sampai batas-batas tertentu yang bisa dijangkau secara akal dan empiris. ${ }^{20}$

Campbell menyatakan, suatu pikiran yang mengandung proposisi "benar dalam teori akan tetapi salah dalam praktik", mempunyai dasar alasan yang berasal dari ketidakmampuan memahami suatu teori yang merupakan kesalahan umum yang terjadi dalam penggunaan proposisi terhadap kejadian-kejadian yang tidak mempunyai kaitan dengan teori yang mendasarinya. ${ }^{21}$ Kenyataan demikian, memang benar terjadi dalam dunia ilmu pengetahuan, khususnya pendidikan, dimana kesalahankesalahan teori dapat membahayakan proses kependidikan yang sedang berlangsung. Oleh karena itu masalah kompetensi (keahlian dalam bidang keilmuan) perlu dikembangkan secara serius.

Bentuk konseptual dari sebuah pemikiran yang menghasilkan teori itulah yang membentuk suatu ilmu pengetahuan. Dilihat dari segi sumber timbulnya, ilmu dapat dibedakan menjadi 2 macam, yaitu: 1 . Ilmu formal, yakni bila didasarkan atas cara berpikir deduktif; 2. Ilmu

\footnotetext{
${ }^{19}$ Nur Uhbiyati, Ilmu Pendidikan Islam, 26-27.

${ }^{20}$ Nur Uhbiyati, Ilmu Pendidikan Islam, 27-28.

${ }^{21}$ Norman R. Campbell, Foundation Of Science: The Philosophy of Theory and Experiment, 120; Lihat dalam Nur Uhbiyati, Ilmu Pendidikan Islam, 28
} 
empiris, yakni bila ilmu pengetahuan itu disusun atas dasar sistem berpikir induktif dan faktual. Ilmu pengetahuan matematika, logika, termasuk ilmu formal; sedangkan ilmu kimia, psikologi dan pendidikan tergolong ilmu pengetahuan empiris.

Suatu teori dikatakan baik apabila disajikan secara singkat, padat dan komprehensif. Di lingkungan dunia ilmu pengetahuan di Barat, teori yang demikian didasarkan atas Hukum Parsimony (Law of Parsimony), yaitu suatu ketentuan yang menyatakan bahwa jika terdapat banyak teori yang dikemukakan tentang masalah yang sama, maka yang diterima oleh ilmu pengetahuan (science) adalah yang paling sederhana. Hal ini sesuai dengan prinsip Qala wa Dalla (yaitu sedikit tetapi jelas); atau dalam istilah ilmu Mantiq disebut dengan istilah Jami' Mani' (pengumpul makna). Hukum parsimony tersebut sering disebut dengan Prinsip Pisau Cukur Occam, karena yang pertama-tama menyarankan agar membuang statement atau keterangan yang tidak perlu, ini diteorikan oleh Wiliam Occam. $^{22}$

Dalam ajaran Islam terdapat ayat-ayat al-Qur'an atau sabda-sabda nabi yang secara implisit mengandung motivasi yang mendorong manusia untuk berpikir dan menyelidiki alam kehidupannya sendiri dan alam kehidupan sekitarnya, dan faktor kemampuan berpikir inilah yang menjadi kriterium antara makhluk manusia sebagai ciptaan Allah yang paling mulia dari makhluk lainnya, sebagaimana firman Allah yang artinya:

"Dan janganlah kamu mengikuti sesuatu pendapat yang kamu sendiri tidak mempunyai pengetahuan tentangnya. Sesungguhnya pendengaran, penglihatan dan hati, masing-masing itu akan dimintai pertanggung jawabannya" (QS. Al-Isra: 36). ${ }^{23}$

Nabi Muhammad juga menyatakan dalam sebuah sabdanya: "Berpikirlah kamu tentang ciptaan Allah dan jaganlah berpikir tentang zat Allah".

Firman Allah yang mengandung motivasi berpikir dan menyelidiki serta melakukan observasi tentang fenomena dari ciptaan

${ }^{22}$ Nur Uhbiyati, Ilmu Pendidikan Islam, 29.

${ }^{23}$ Al-Quran dan Terjemahnya, 429. 
Allah disebut dalam Al-Qur'an sampai \pm 300 kali. Kenyataan tersebut menunjukkan bahwa fungsi berpikir menjadi unsur utama kehidupan manusia dalam pengembangan ilmu pengetahuan baik untuk penyempurnaan hidup beragama maupun bagi kemajuan dan kesejahteraan hidupnya di dunia. Hal yang menjadi permasalahan penting adalah bagaimana menyusun buah pikiran kedalam bentuk yang sistematis, logis, konsisten dan konsepsional serta operasional dengan tujuan yang jelas dan tidak menyimpang dari tata nilai dan moral agama. Inilah yang menjadi tumpuan cita-cita umat Islam dalam usaha mengembangkan Ilmu Pengetahuan Islam atau Ilmu Pendidikan Islam, teoritis maupun aplikatif.

Ketika ilmu pengetahuan teoritis telah tersusun baik, maka sistematika penyusunanya harus memiliki bentuk (struktur) yang mengandung substansi (bahan-bahan) yang pengertiannya satu sama lain berkaitan serta berkesinambungan yang bersifat utuh atau integral. Metode-metode ilmiah yang diterapkan dalam studi dan analisis bahan harus mempunyai watak atau corak khas dari bidang keilmuan yang bersangkutan, misalnya, pendidikan Islam sebagai suatu ilmu memerlukan sistem dan metode analisis yang didasarkan atas pendekatan-pendekatan fiilosofis, religius pedagogis, dan psikomotorik terhadap sasaran-sasaran analisis atau kajian yang mendalam.

Sistem dan metode yang digunakan di dalam ilmu alam, yakni kausal verklaring (sebab-akibat) adalah tidak selalu relevan dengan corak dan watak keilmuan dalam pendidikan, yaitu hukum perkembangan. Ilmu pengetahuan alam mempunyai sasaran analisis berupa benda-benda mati yang tunduk kepada hukum-hukum alam yang sudah pasti, misalnya, bila zat hidrogen dengan valensi 2 disenyawakan dengan zat oksigen, maka sudah pasti menghasilkan zat yang berupa air. Proses serupa dapat menimbulkan hasil yang sama meskipun dilakukan percobaan berulangulang. Sementara itu, perkembangan keilmuan dalam pendidikan merupakan proses yang mengandung sifat yang lentur dan relatif dalam mencari kebenaran ilmiah melalui kegiatan studi yang dilakukan. 


\section{F. Kesimpulan}

Persoalan pendidikan Islam tidak dapat dilepaskan dari beragam persoalan yang lainnya. Pendidikan Islam selalu terkait dengan berbagai elemen kehidupan, terutama manusia. Melalui pendidikan Islam manusia dapat tumbuh dan berkembang dengan baik. Sebaliknya, manusia (Muslim) menjadi aktor dari maju atau mundurnya pendidikan Islam. Antara umat Islam dan pendidikan Islam merupakan dua hal yang dapat diibaratkan seperti sekeping uang, yakni terdiri dari dua sisi yang berbeda tetapi tidak terpisah antara satu dengan lainnya.

\section{DAFTAR PUSTAKA}

Abdurrahman Wahid, Menggerakkan Tradisi, Cet. II (Yogyakarta: LKiS, 2007).

Abd. Chayyi Fanany, 2010, Ilmu Pendidikan Islam (Surabaya: Taruna Media Pustaka).

Anwar Rasyid, 2011, Ilmu Pendidikan Islam (Teori \& Aplikatif) (Surabaya: TMP).

M. Jindar Wahyudi, 2006, Nalar Pendidikan Qurani (Yogyakarta: Apeiron Philotes).

M. Arifin, 1977, Psikologi dan Beberapa Aspek Kehidupan Ruhaniah Manusia (Jakarta: Bulan Bintang).

Nur Ubiyati, 1999, Ilmu Pendidikan Islam, Cet. II (Bandung: CV. Pustaka Setia).

YPP, 1971, Al-Quran dan Terjemahnya (Jakarta: Yayasan Penyelenggara Penterjemah/Pentafsir Al-Quran).

Zakiah Daradjat, 2008, dkk, Ilmu Pendidikan Islam, Cet. ke 8 (Jakarta: Bumi Aksara-Depag RI). 